\title{
Buenos Aires como escenario: hacia un decálogo de vínculos entre lo urbano y lo teatral
}

Malala González

Universidad de Buenos Aires, Argentina

malalagonzalez22@gmail.com

Fecha de recepción: 30/03/2019. Fecha de aceptación: 12/05/2019.

\begin{abstract}
Resumen
En el siguiente artículo nos proponemos indagar algunas articulaciones entre lo teatral-performático y la ciudad, a partir de diferentes prácticas, vínculos y relaciones que permitan repensar a Buenos Aires desde su configuración urbana como escenario, su memoria cultural y su cuestión patrimonial. Desde resabios de tiempos pasados -que no sólo se sedimenten en lo particular o singular de la experiencia artística, sino que entren en diálogo con cuestiones de pertenencia, de identidad o de historia socialmente compartida-, o de huellas y acervos más tangibles -desde lo arquitectónico, lo documental o lo dramatúrgico/escénico- nos proponemos armar un decálogo de modalidades que posibiliten cruces posibles entre el presente y el pasado del paisaje que habitamos. Y desde allí observar cómo, en cada caso, se convoca una mirada sensible que habilita otra percepción, poniendo en práctica la memoria o, simplemente, deconstruyendo lo urbano para otorgarle nuevos sentidos.
\end{abstract}

\section{Buenos Aires as a Stage: Towards a Decalogue of Links between the Urban and the Theatrical}

\begin{abstract}
In this article, we aim to reflect on some possible connections between theatre/performance and the city, considering different practices, links and relations that allow us to rethink Buenos Aires as a stage based on its urban configuration, its cultural memory and its heritage. We intend to put together a decalogue of modalities that enable the intersection between the present and the past of the scenery we live and to observe how, in each case, they call for a more sensitive look that can experience a different perception of the urban, incorporating other practices of memory, other deconstructions, and, thus, providing new meanings.
\end{abstract}

Palabras clave

Teatral/performático Ciudad memoria urbana tangible/intangible patrimonio cultural

Keywords

Theatre/performance City

Urban Memory

Tangible/Intangible Cultural Heritage 


\section{Introducción}

Toda ciudad se constituye sobre dos modos de ser que conviven en ella a diario: uno tangible y otro intangible. Por su condición, uno estaría al alcance de lo que vemos, oímos, tocamos o pisamos como paisaje urbano; mientras que el otro plantearía una percepción interpretativa diferente, ligada justamente a cómo nos conducimos en tanto ciudadanxs sobre aquello material. Es decir, junto con las fachadas de edificios de diferentes estilos arquitectónicos o con la diagramación y ubicación de calles y veredas del mapa urbano habita también la historia cultural de esos espacios, sus usos y costumbres que, según los tiempos, se despliegan a partir del hacer de quienes viven o transitan la ciudad. Así, sobre este gran escenario de coexistencia espacio-temporal, en el que el pasado y el presente fluctúan constantemente, se extienden estos dos modos de ser.

A partir de este juego de niveles, el plano de lo intangible, a primera vista, parecería señalar una desventaja frente a lo material, pues por su condición no tendríamos aquello por indagar y su reconstrucción se volvería un trabajo aún más complejo dentro del tejido urbano. Reflexionar sobre ello implica abordar un aspecto que conjuga intrínsecamente una problemática puntual presente en el estudio de las ciudades: el patrimonio cultural intangible. Identidad, tradición, historia, memoria, monumentos, bienes culturales y simbólicos compartidos, conservación, restauración, son términos que lo rodean y así logran determinar su uso. Sin embargo, en la actualidad, éste sigue repensándose mediante articulaciones que lo involucran con diferentes esferas sociales y que plantean nuevas formas de territorialización y problematización en tiempos donde las ciudades han crecido y donde la globalización barre paradigmas de conservación más tradicionales (Canclini, 1993). Por ello, hablar hoy de patrimonio es repensar los modos de hacer practicar la memoria urbana. Teniendo en cuenta este panorama, en el siguiente trabajo nos proponemos abordar algunas manifestaciones de lo intangible en la ciudad a partir de variables que propone lo teatral, sobre lo cual estaríamos incluyendo múltiples aristas que rodean al teatro y su actividad.

Efímero por condición, lo teatral nos permitirá ir en busca de articulaciones de memoria urbana que plantean cruces entre lo material dado y lo intangible conviviente y latente. Una fachada de una sala teatral algo antigua, una intervención urbana performática en una esquina, una obra de teatro callejero en una plaza, por sólo nombrar algunos acontecimientos que instalan otras miradas sobre el paisaje cotidiano, serán parte de ese otro orden que convive en el espacio público, generando otros espaciostiempos posibles y convirtiendo -momentáneamente o no- a lxs ciudadanxs en espectadorxs. Nos proponemos reflexionar sobre aquello que -desde alguna relación con la memoria- de algún modo puede emerger dentro del tejido urbano presente. Es decir, indagaremos acerca de prácticas, modalidades, acciones que activan otras miradas e imágenes dentro del espacio público, ya sea como resabios de tiempos pasados o recientes que, a partir de algún gesto arqueológico artístico, logran reactualizarse, o manifestaciones más actuales que ponen en tensión cómo y qué recordar. Estamos pensando una memoria urbana cultural y compartida que no sólo se sedimente en lo particular o singular de la experiencia artística, sino que entre en diálogo con cuestiones de pertenencia, de identidad o de historia social compartida. Inclusive, en memorias más tangibles que -desde lo arquitectónico o lo textual dramático-ya nos planteen una relación con un tiempo pasado en su misma estructura o configuración. Intentaremos, entonces, reflexionar acerca de esto, de esas miradas sobre la ciudad tangible e intangible, pero perceptibles al fin desde una dimensión estética (Aguilar, 2006). Reposaremos en prácticas que pongan en tensión el paso del tiempo al aplicar resistencias sobre el olvido, o bien que tiendan a modificar por un instantes el modo de percibir o recorrer la propia ciudad. Pero, ¿cómo reunir dentro de un mismo análisis prácticas que pueden sean muy disímiles entre sí, pero que logren visualizar ese factor común de articulación entre memoria urbana, teatro e historia cultural? 
El desafío consistirá en confeccionar un decálogo que ubique los diferentes casos desde los cuales poder pensar cada modalidad. Partiendo de la hipótesis de que es en el espacio público -en tanto escenario cotidiano y escenario de acción artísticadonde se manifiesta la ciudad material e inmaterial, intentaremos enumerar algunas modalidades de lo teatral que fluctúan sobre ella apelando, entre otros aspectos, a una memoria urbana en reconstrucción. Es decir, abordaremos diez cruces diferentes de interacción con lo teatral: teatro de calle convencional, performances urbanas más esporádicas, intervenciones teatrales en espacios culturales, teatro comunitario, espacios teatrales que puedan o no continuar permaneciendo materialmente dentro del mapa urbano, espacios híbridos entre el teatro y la vereda, festejos en el espacio público oficiales y contraoficiales, centros de documentación teatral, derivas urbanas y dramaturgias que evocan la ciudad. En ellos observamos cómo la ciudad y el arte teatral/performático se entrelazan a partir de diferentes usos del espacio público, los cuales oscilarán entre una memoria teatral pasada y lo que queda de ella luego de este suceso en tanto huella urbana, o a la inversa. Es decir, así como lo teatral extracotidiano puede ser parte de lo efímero que activa una memoria posible (al evocarla o relatarla), a la inversa, puede que algo material, documental y hasta arquitectónico teatral actual se convierta en huella de un pasado urbano acontecido. Sobre estos dos sentidos del recorrido que habilita la memoria de la ciudad-apoyados en los binomios pasado/presente y material/intangible- plantearemos nuestro decálogo.

\section{Posible decálogo de cruces entre lo teatral y lo urbano}

Lejos van quedando los monumentos fijos, volviéndose endebles frente a lo efímero y performático que sucede en la ciudad. Una memoria urbana que se metamorfosea a partir de nuevos modos de entender el pasado, de aquello que, de pronto, reaparece, emerge, generando otras aristas y capas de sentido sobre la(s) historia(s) de una ciudad. Lugares que nos hablan del paso del tiempo y de lo acontecido en ellos como memoria en constante reconstrucción, junto con una preponderancia de lugares destinados a ejercitar y repensar la memoria (Norah, 1997), que colaboran en señalizar parte de este cambio de paradigma contemporáneo palpable dentro del paisaje urbano actual. De algún modo, esto es reflexionar sobre el patrimonio, sobre aquello que es herencia y es valorado o merece serlo para la posterioridad. Y para lo cual, el acto de recodar siempre será contingente y determinante respecto de su sitio y tiempo de emplazamiento, manteniendo una estrecha relación con la historia de ese lugar, con el arraigo y con la posibilidad de plantear dos tiempos: el pasado y el presente de manera dual.

Ahora bien, nuestro tiempo presente tiene algo de desarraigo, de cierta desterritorialización al colaborar en una suerte de desaparición de la trayectoria de las cosas (Chul Han, 2015:42) y por ello habría cierta necesidad de pensar lo intangible como aquella (in)materialidad propicia para generar el recuerdo. De ahí que lo performático (como práctica de la memoria) y la gestión patrimonial puedan resultar modos o iniciativas para colaborar con tal fin.

Ahora bien, pensemos en reconciliaciones con el pasado, en imágenes latentes de un mapa urbano que se restituyen desde lo teatral, en momentos teatrales que no quieren ser olvidados y que se conservan en documentos y programas de mano de un archivo de una sala teatral, o en textos dramáticos que evocan esquinas puntuales de la ciudad, en textualidades híbridas que plantean nuevos modos de acercamiento con lo urbano como las derivas performáticas por algún barrio, en límites desdibujados entre realidad y ficción, alterados. Es en estas articulaciones urbano-teatrales donde aparece la posibilidad de suspensión del ser ciudadanx cotidianx para, momentáneamente, percibir con otros ojos lo que nos rodea. Ojos para un tiempo otro, cual mirada dialéctica benjaminiana (Vedda, 2008). 
Esta mirada otra que se propaga sobre la ciudad no deja de percibir ese escenario mayor con el que entró en relación por ser parte de. Lo que rodea espacialmente al acontecimiento artístico, lo que lo atraviesa y/o lo hace resonar y desplegar sentidos, ya sea, por ser parte de una ciudad, de un campo teatral determinado, de una época puntual, se vuelve escenario urbano contextual. Expandirlo, estirarlo, hacerlo ambiguo, hacerlo dialéctico y heterotópico, es la cuestión. Porque sigue siendo un espacio que veo, la ciudad, pero que a partir del tiempo de la obra, o las obras que sucedieron allí, puedo mirar a la ciudad de manera diferente. En definitiva, se trata de atender al lenguaje teatral/performático superpuesto con el lenguaje urbano ordinario. Hacia estas combinaciones nos dirigimos en la siguiente enumeración de variables. Ciertamente, la misma será arbitraria en su selección heterogénea pero, sin embargo lo que nos proponemos pensar a partir de ella es justamente los diferentes modos de abordar dicha articulación entre arte y ciudad manifiesta.

\section{Articulación No. 1: El teatro de calle convencional}

Dentro del espacio público, un grupo de actores o actrices realiza una convocatoria previa. Avisan que pronto habrá teatro en esa porción de plaza para que lxs transeúntes invitadxs puedan convertirse en posibles espectadorxs. Se demarca un espacio de acción, la ronda, y los personajes se identifican a partir de un vestuario teatral (que puede incluir zancos, medias máscaras, pelucas). En este caso opera la convención teatral general, advierten que la obra está por comenzar y el pacto se establece, aun cuando el lugar no sea teatralmente convencional. Reunión, empatía con el público, divertimento familiar, a partir de personajes que amplifican su corporalidad y capacidad vocal para ser vistos y escuchados en la calle como lugar de acción. Lo teatral expandido hacia la ciudad tomada como escenario. En esta primera articulación entre lo teatral y lo urbano, el acontecimiento efímero surge como posible irrupción y elige determinada esquina o parque. Ejemplos de esto serían los grupos surgidos en los años 80, con el retorno democrático, tales como Teatro de la Libertad, el Grupo Dorrego, Diablomundo, entre otros; o bien en la actualidad, grupos como La Runfla de Parque Avellaneda, que desde hace años utiliza dicho parque como su gran sala teatral. De todos modos, cabe señalar que el teatro de calle tiene un largo recorrido dentro de la historia del teatro universal y que, desde tiempos remotos, la calle ha sido siempre un posible escenario de acción hegemónico y contrahegemónico. Dentro del planteo de este decálogo, observar espacios intervenidos por esta acción puede retrotraernos a una coyuntura especial como ser un reforzamiento ideológico de lo democrático y de lo público, como resultó durante la posdictadura, o bien dar cuenta de un pasado urbano teatral que descansa en la memoria de sus propias calles y plazas.

\section{Articulación No. 2: Las performances urbanas}

Dentro del espacio público, habría otros modos de disrupción del tiempo ordinario. Sin avisar de la acción por acontecer, esta sucede mediante la sorpresa, el shock e interpelación con lxs transeúntes desprevenidx, quienes se vuelven espectadorxs cuando la acción ya está sucediendo, si es que logran enterarse de la misma. Así en la calle puede instalarse una teatralidad por parte de los performers pero no ser advertida por lxs transeúntes (Féral, 2004), al desdibujarse los límites entre ficción y realidad de manera liminal (Diéguez Caballero, 2007). Al no anticiparse previamente, al no demarcar el espacio escénico elegido, estas acciones juegan con ese no límite y pliegues de sentidos sobre lo urbano. Son prácticas heterogéneas que desde lo material urbano como escenario hacen surgir lo intangible performático. Pueden no utilizar un vestuario vistoso, pueden ser muy breves y espontáneas, pueden solaparse con lo cotidiano y desde allí interpelar súbitamente. Un ejemplo de esto serían las performances urbanas de La Organización Negra durante 
los años 80, cuando irrumpían semáforos, galerías comerciales o peatonales llamando la atención de quienes pasaban por el lugar, sin explicar quiénes eran, porqué lo hacían, ni qué significaba su hacer, tan sólo quería ganarles a la vidrieras, marcar un tiempo otro en un horario habitual de la gente (González, 2015). O bien las performances instaladas en el subterráneo, como teatralidad invisible, de la mano de Augusto Boal (Féral, 2004). En la actualidad existen varios colectivos artísticos que proponen acciones performáticas sobre la ciudad como las realizadas por la Fuerza Artística de Choque Comunicativo (FACC) en contra de la violencia institucional, llevando su fuerte presencia a espacios donde puede haber un conflicto socio-político. Esto no sólo en Buenos Aires, sino también en diversos puntos del país y hasta en simultáneo ${ }^{1}$. En este caso, el registro de sus acciones, por tratarse de otros tiempos cibernéticos a los de La Organización Negra, en seguida es compartido en las redes sociales, generando imágenes muy contundentes que interpelan directamente a espectadorxs virtuales desde una coyuntura muy actual. En varias oportunidades, notamos que el grupo no ha empleado el habla, sino tan sólo la presencia y la quietud de cuerpos dispuestos de una forma determinada con máscaras de la peste. Poner el cuerpo, esos cuerpos colectivos en la calle, en espacios determinados, políticamente instala, como su nombre grupal lo indica, un choque visual, que pretende comunicar una problemática social-institucional-política puntual capaz de tensionar aspectos de nuestra historia reciente.

\section{Articulación No. 3: Iniciativa oficial Vs. Acción periférica}

Teniendo en cuenta la articulación anterior, pensemos en una variable que se establezca como intervención urbana pero cuya procedencia y modos de producción-circulación y consumo, sea lo que la determine considerablemente. Al repensar las miradas, los usos y la memoria dentro del espacio público, observamos que varía ampliamente la condición de aquello que sí está permitido, que ha sido habilitado y que cuenta con apoyo para su realización, respecto de aquello que no. Es decir, si la acción artísticopolítica es contracultural, periférica su manifestación dentro del espacio público será, al menos diferencial, de aquello que pertenezca a una programación oficial o a un encargo estatal. Pensemos en festejos públicos, en espectáculos al aire libre como apertura de festivales artísticos, allí cuando la intervención es oficial suele estar programada, anticipada, advertida para lograr mayor asistencia y convocatoria. Y suele tener un aparato y organización logísticos que se encargan de que todo salga como se programó. Es decir, habría un marco de contención de la acción que, por el tiempo que ésta dure, admitirá esa porción de la ciudad como un escenario. Ejemplo de esto serían los festejos oficiales por la conmemoración del Bicentenario nacional, en mayo de 2010, cuando el grupo performático teatral Fuerza Bruta fue contratado por la Unidad Ejecutora del Bicentenario para realizar un mega desfile artístico-histórico como clausura de dichos festejos. El alcance, la promoción, el desarrollo de esta intervención como manifestación sobre el espacio público contó con un gran apoyo, no sólo económico, sino, como decíamos logístico, en el que la intervención urbana estaba esperada. Y si bien fue efímero por condición, su recuerdo dentro de la historia teatral urbana quedará para la posteridad como una intervención monumental. En este mismo sentido, pensando en antecedentes estéticos y grupales de dicha intervención, en 1989 con la Tirolesa/Obelisco llevada adelante por La Organización Negra ocurrió algo similar. En aquel momento fue la Secretaría de Cultura la que auspició el empleo extracotidiano del monumento más emblemático de la ciudad; es decir, no fue cualquier día, ni un momento disruptivo en el que unos performers se colgaron del Obelisco, sino que la acción contó con una organización y planificación previas y acordadas que permitieron su realización. Si bien estos dos ejemplos pueden resultar paradigmáticos y diferenciales incluso de algunas prácticas que también cuenten con apoyo estatal, resulta interesante observar cómo opera la delimitación del espacio público intervenido en estos casos, es decir, cómo se delimita el espacio de acción dentro de un espacio mayor, la ciudad. Nos referimos
1. Para más información léase: http://www.diariopublicable. com/cultura/7727-si-nointerpela--no-es-arte.html 
a que el marco del acontecimiento opera como delimitación física espacial no casual, sino preparada para tal fin, lo cual propone una mirada distinta sobre la ciudad, de pronto, más espectacular, y cuyxs espectadorxs se predisponen para tal rol de modo diferente, incluso anticipado.

Todo lo contrario ocurre con aquello que no se espera que suceda en el espacio público, aquellas prácticas que no cuentan con apoyo gubernamental-estatal, ni logístico y que, justamente, tampoco lo suponen. Acciones más disruptivas que juegan con ese riesgo de lo inesperado dentro del tejido urbano, con la urgencia del hacer que pueda poner en relieve otros sentidos estético-políticos, más provocadores, menos consensuados. Ejemplo de esto serían las acciones de las FACC (mencionadas en el caso 2), que se posicionan en el límite de lo permitido, expandiendo su uso durante un momento determinado, por lo que esta variable contracultural de intervención sorpresiva es el motor de su acción. En este tipo de intervención urbana instalado sobre el margen, incluso menos relevado por la prensa, lo efímero se vuelve aún más escurridizo de documentar o registrar, si pensamos en imágenes que componen la historia cultural de nuestra ciudad. Son prácticas que, como decíamos al inicio de este trabajo, plantean esa doble complejidad de estudio sobre lo patrimonial intangible, aún más difícil de reconstruir en una ciudad vuelta escenario.

\section{Articulación No. 4: Intervenciones teatrales en ámbitos culturales, no teatros}

En este caso, reuniríamos acciones teatrales que escapan a su ámbito tradicional- la sala teatral, para desplegarse por otros ámbitos, tales como museos, centros culturales, institutos. Es decir, teatro fuera del teatro, a partir del cual se desarrolla una representación teatral capaz de generar vínculos con contenidos institucionales propios del espacio cultural intervenido. Esto plantea otros modos de percibir el propio lugar de acción, mediante la hibridez de lenguajes artísticos. Un claro ejemplo serían las visitas guiadas teatralizadas en museos que colaboran en comunicar el acervo de obras exhibidas, desde otras perspectivas composicionales y aportando desde lo performático-teatral modos diferentes de recepción/interpretación sobre ellas. Evidentemente este juego de lenguajes permite otro tipo de espectadorxs-visitantes, roles que se actualizan a partir de la propia acción teatral interventora. En 2015, hubo un programa de promoción de los museos que contaban con apoyo institucional oficial, denominado Ronda cultural. El mismo proponía recorrer tres museos durante una misma tarde a partir del traslado en combis. En el tercer museo visitado acontecía la intervención performática-teatral. La realizada en el Museo Histórico Nacional, de Parque Lezama consistía en expandir teatralmente diferentes obras allí exhibidas. El cuadro que rememora la primera vez que se cantó el Himno Nacional cobraba vida a partir de dos actrices, dos actores y un músico que entonaban parte de la canción patria en el sector dedicado a las sociedad porteña de 1810 y a los modos de sociabilidad de la aristocracia de entonces; más tarde, el sector de pueblos originarios se llenaba de música ejecutada con instrumentos precolombinos; mientras que, en otro rincón, la visita continuaba con un candombe en vivo y había baile con tambores para generar otro relieve en los cuadros vinculados con la cultura afro. Aquí el recorrido cobraba un sentido en torno al patrimonio cultural material institucional, superpuesto a nuevas artes que emergían dentro de ese ámbito.

\section{Articulación No. 5: El teatro comunitario}

Esta variable de articulación entre arte y ciudad se corresponde con una modalidad teatral que ya tiene varias décadas de trayectoria en la ciudad de Buenos Aires, el 
teatro comunitario. En ella, la utilización del espacio público o bien una sala teatral propia dentro del barrio fundador se vuelve extensión del propio lugar de convivencia vecinal. Su actividad y desarrollo suelen estar estrechamente vinculados con la historia de ese lugar habitado, con lxs vecinxs que pertenecen de esa porción geográfica de la ciudad a partir de lo cual, por lo general, sus obras se constituyen como una fuerte resistencia política al olvido, recuperando la memoria de historias del barrio o de quienes lx habitaron, estableciendo un fuerte vínculo de pertenencia comunitaria. En cuanto a lxs espectadorxs, estxs son advertidxs del acontecimiento u obra por suceder, en muchos casos pueden ser lxs propixs vecinxs y hasta llegar a convertirse en próximos actores/actrices de futuros espectáculos, o espectadorxs de otros lugares. Cabe señalar que en los procesos creativos aparece una fuerte vinculación con la historia oral como fuente de construcción dramatúrgica. Ejemplo paradigmático de esta variable es el grupo Catalinas Sur, fundado y dirigido por Ademar Bianchi en el barrio de La Boca, el cual cuenta con sala propia, talleres de formación artística, en un predio conseguido luego de mucho trabajo. Entre sus producciones se encuentran: $E l$ fulgorargentino, Venimos de muy lejos y Carpa quemada. Otros grupos son Mate murga, en el barrio de Villa Crespo, dirigido por Edith Scher, o el Circuito Cultural Barracas, dirigido por Ricardo Talento.

En esta variable podríamos pensar que el vínculo urbano-teatral se establece desde lo inmaterial testimonial o lo material del barrio, hacia lo efímero de la escena estrenada, organizada y constituida colectivamente, la cual genera, entre otros aspectos, una sociabilidad adquirida fruto del encuentro y reunión entre vecinxs.

\section{Articulación No. 6: Los espacios teatrales dentro del mapa urbano}

En este caso pensamos a las salas teatrales convencionales que, de por sí, advierten, señalan y localizan que -desde un sentido material arquitectónico- dentro de ellas acontece teatro. Aquí el vínculo entre urbano-teatral opera por convención. En Buenos Aires existen actualmente cerca de doscientas treinta y tres salas teatrales distribuidas en ciento noventa y nueve teatros; ocho de los cuales corresponden al circuito oficial; veintiocho al comercial y ciento sesenta y tres al independiente (González, 2016). A partir de su ubicación y fachadas edilicias visibles podríamos recorrer la ciudad, estableciendo circuitos teatrales posibles. Por ejemplo, recorrer los teatros comerciales de la Avenida Corrientes -tales como el Astral, el Opera, el Tabaris, el Gran Rex, El Nacional, por mencionar sólo algunos-; o bien ir en busca de salas independientes del "circuito Abasto" -El camarín de las musas, el Beckett, el futuro Teatro Del Pueblo, El extranjero, entre otros-. Cualquiera de estos posibles recorridos no resultaría complicado si tenemos las direcciones de las salas y un mapa de la ciudad.

Sin embargo, dentro de esta categoría podríamos incluir no sólo los espacios teatrales actuales, sino sumar aquellos que ya no existen materialmente en la ciudad -porque han sido demolidos- pero que claramente dan cuenta de un pasado teatral, de una época, de modos de sociabilidad correspondientes, de arquitecturas y capacidad según la demanda de público, y que también constituyen parte del patrimonio intangible teatral de Buenos Aires. En este sentido, un posible recorrido podría trazarse dentro del casco histórico de la ciudad, en el cual se podrían evocar: el Colón antiguo (Reconquista y Rivadavia), el Coliseo Provisional (Reconquista y Perón), el Teatro De la Victoria (actual Bartolomé Mitre y Bernardo de Irigoyen), el Teatro Casino (Maipú y Corrientes), hasta la propia Ranchería (Moreno y Chacabuco), entre muchos otros espacios de fines de siglo XVIII en adelante. Trazar esta cartografía de espacios que ya no están, nos hace preguntarnos si la ciudad no sería también "una imagen capaz de contener la memoria de todo lo que no pudo ser o de aquello que desapareció" (Ballent, et al, 1993:83). Cartografías teatrales pasadas que plantearían así un recorrido 
que iría de lo material urbano actual hacia el pasado de esos lugares, a fachadas que ya no existen, pero que pueden ser evocados, retomados, recordados como postales intangibles. pero latentes dentro del mapa actual. Por lo que, tanto estos espacios, como los actuales, conformarían, como decíamos, el patrimonio arquitectónico teatral y cultural de la ciudad.

\section{Articulación No. 7: Extensión de espacios teatrales- Espacios híbridos}

En este caso pensamos en una combinación espacial entre lo teatral y lo urbano dada a partir de la extensión del espacio escénico propiamente dicho hacia la vía pública. Situaciones que, previamente a la representación dentro de un teatro, se manifiesten en las afueras del mismo. Seguramente, esta prolongación de lo escénico interviniendo parte del espacio público circundante debería proponer ampliar algún sentido particular sobre lo próximo a ver dentro de la sala o, al menos, eso suponemos. Por ejemplo, actores y actrices empleando el mismo vestuario que en la obra por acontecer, establecen diálogos o realizan acciones específicas que se relacionan con lo que luego se verá. Estos prólogos híbridos proponen otro tipo de percepción sobre lo teatral y lo urbano, ya sea porque preparan a lxs espectadorxs y predisponen un marco anticipado sobre el hecho escénico, como así también pueden promocionar el espectáculo, convocando la mirada de transeúntes que no vayan a asistir en ese momento a la obra, pero que sí observen al suceso como parte de un espectáculo posible de ver. De todos modos, puede ocurrir que ese suceso híbrido -entre lo teatral que sucede dentro de la sala y la propia intervención urbana de la vía pública/vereda o puerta del teatro- se dé durante la representación, haciendo un corte, una interrupción de aquella mirada más convencional. Pensamos en este caso a la obra El tiempo, perteneciente al Proyecto Pruebas de Matías Feldman, que se llevó a cabo en el 2016 en el Teatro Sarmiento del Complejo Teatral de Buenos Aires. Se trató de una instalación detenida en la explanada que ocupa parte de la vereda del teatro. Allí numerosxs actores y actrices participaban de varias estampas, por cierto no detenidas, sino llevadas a un movimiento mínimo casi imperceptible, componiendo imágenes degradadas por ese ínfimo paso del tiempo, explorado como acción teatral. Decía Feldman al respecto:

Que el acontecimiento quede frenado en un lugar, pero que el tiempo, como se trata de teatro y no de una foto, siga transcurriendo. En esta prueba, el tiempo no avanza de la manera clásica, cronológicamente, sino verticalmente, ralentizado. La idea fue generar una dramaturgia del instante. Hay una riña callejera entre dieciocho jóvenes: algunos escolares, otros vestidos de basquetbolistas... Y unas cajas llenas de VHS que son volcados en el piso. Cada imagen explota y salpica para muchos lugares. Uno piensa de dónde vienen y hacia dónde van esas situaciones, que no son temáticas. Se puede proyectar sobre ellas el tema que quieras (2016: $\mathrm{s} / \mathrm{p})$.

Y en eso consistía la prueba/instalación, dotar de sentido esas imágenes, tanto para quienes salían de la sala para ver la tercera prueba allí instalada, como para aquellxs que pasaban por la manzana del zoológico y se sorprendían al encontrar una escena diferente, poco urbana y muy teatral. En este sentido, la intervención estaba en estrecha relación con lo que se proponía la totalidad del espectáculo dentro de la sala, en tanto marco/proyecto en el que acontecía. Sin embargo, al ampliar su espacio escénico y al elegir la calle como escenario de acción, nuevas perspectivas y sentidos se desplegaron, más allá de lo teatral. Porque, como venimos señalando, la intervención de lo urbano habilita nuevos sentidos sobre este paisaje. Por otro lado, este caso puntual de la intervención de Feldman, también se podría asociar a la articulación No. 3 de 
este decálogo ya que, en términos de propuesta intervención de la vía pública oficial, fue parte de la programación de un teatro público. Es decir, como intervención de la explanada del Teatro Sarmiento estaba programada y legitimada por la sala, por lo que su accionar estaba permitida para realizarse todas las semanas de función.

\section{Articulación No. 8: Las derivas urbanas}

Otra variable de articulación teatral-urbana podrían ser las derivas que, en términos de Guy Debord, se trataría de maneras de "errar en la ciudad para descubrirla como una red narrativa, de experiencias y de vida. Es una iniciativa que consiste en desplazarse a través de distintos ambientes de un espacio (una ciudad, un barrio...) y dejarse guiar por sus afectos" (Giunta, 2014:51). En efecto, el recorrido por algún barrio de Buenos Aires a partir de una deriva performática puede ser otro modo para repensar la vinculación de la ciudad como escenario. En este caso, un ejemplo concreto son los recorridos que realiza la Compañía de Funciones Patrióticas, mediante sus Relatos situados (2015-en adelante). El recorrido efectuado por el barrio de Almagro consiste en cartografiar y señalizar un camino a partir de algunas baldosas de la memoria -las cuales recuerdan a lxs desaparecidxs de la última dictadura militar-retomando las historias de vida de sus protagonistas, pero también narrando relatos vinculados a la experiencia de percepción de la ciudad para conmemorar con otros sentidos y pliegues posibles de memoria urbana latente (González, 2018). La posibilidad de caminar por el barrio, de escuchar sobre su historia, al ser conducidxs por performers guías y de volver al punto de encuentro para poder verbalizar la experiencia, es una propuesta que apela a la participación de espectadorxs en roles de transeúntes activxs desde la historia reciente. La propuesta no establece un vínculo con lo espectacular, sino todo lo contrario, se apoya en la experiencia y contemplación individual, subrayando lo subjetivo en primera persona. Se trata de hacer hablar al contenido urbano que nos rodea, a heridas sociales no suturadas, a partir de la emergencia de nuevas miradas.

\section{Articulación No. 9: Los Centros de documentación e investigación teatral}

Dentro de algunos teatros disponemos de centros de documentación e investigación que permiten establecer un vínculo muy estrecho con la memoria urbana. En ellos se mantiene vigente una política de preservación y de archivo sobre materiales que documentan parte de la historia teatral de nuestra ciudad. Tal es el caso de algunos teatros oficiales, como el Complejo Teatral de Buenos Aires y, en particular ,el edifico del Teatro General San Martín, o el Nacional Cervantes, donde funciona el Instituto Nacional de Estudios de Teatro (INET) y su biblioteca, en ellos se concentra un material histórico disponible para la consulta que abarca desde programas de mano de obras realizadas dentro de estas instituciones teatrales hasta diferentes tipos de documentos (registro audiovisual de obras, libros, materiales periodísticos, anuarios, etc.). Si bien el acervo cultural y documental de estos lugares-archivos no sólo responden a vincular el pasado teatral con lo urbano, sí resulta pertinente pensar que estos lugares son propicios para resguardar ese patrimonio cultural teatral intangible que aquí venimos tratando. Porque estos centros tienden a resistirse contra el olvido y a partir de materiales tangibles logran dar cuenta de aquello efímero acontecido en la ciudad.

\section{Articulación No. 10: Dramaturgias que evoquen la ciudad}

Llegamos al final del decálogo, y dejamos como última variable la posibilidad de relacionar la ciudad con el teatro cuando ésta se hace explícita como referencia dentro 
de una obra. Es decir, incluiríamos en este caso a los textos dramáticos que retoman en sus relatos alguna porción de la ciudad, ya sea enunciando sus calles, esquinas, o sucesos puntuales, y que, al mismo tiempo, esta acción de focalizar sobre lo urbano permita el registro o evocación de un espacio público intervenido. En la literatura esta relación se presenta en numerosas obras de autorxs que localizan dentro de Buenos Aires diferentes prácticas, aspectos, sucesos; sin embargo en materia teatral esto no suele ser tan recurrente, aunque afortunadamente encontramos algunos ejemplos. Tal es el caso de la evocación de costumbres y usos urbanos, como el carnaval de principio de siglo XX que pasaba por la calle Pasco en el barrio de San Cristóbal y que la colmaba de gente, a partir de lo cual el motorman debía detener el recorrido del tranvía por tal suceso festivo, o la mención del teatro Marconi que se pueden encontrar en la obra Los disfrazados, de Caros Mauricio Pacheco de 1906. Pero, en ejemplos más actuales, podríamos mencionar la obra Cactus Orquídea, de Cecilia Meijide donde el bar Los Galgos, el Puente de la Mujer de Puerto Madero, hasta el Museo Nacional de Bellas Artes, adquieren un protagonismo como locación a lo largo de toda la trama dramática. De algún modo, poder evocar la ciudad es contar algo de ella y el registro dentro de un texto dramático puede resultar, además de poético, un modo diferente de mirar ese espacio urbano, si todavía existe en la actualidad. En este sentido, el teatro colaboraría en develar aspectos de la propia ciudad, dar a conocerlos, o bien resaltarlos.

Otro ejemplo de evocación y referencia urbana, pero no sólo desde lo dramatúrgico, sino desde una perspectiva escénica performática serían Proyecto Museos (1994-2001), curado por Vivi Tellas dentro del Centro Cultural Rojas, y el ciclo de conferencias performáticas Territorios en conflicto (2017), curado por Gabriela Massuh y Carlos Gamerro, realizadas en el Teatro Nacional Cervantes. En relación con el proyecto de Tellas, ella convocó a diferentes directores teatrales para que, tomando como eje diferentes museos no artísticos de la ciudad -tales como el Museo Histórico Nacional, el Museo Penitenciario, el Museo Aeronáutico, el de la Morgue- retomaran parte de sus acervos documentales para contar sobre ellos interviniendo algún rincón del Centro Cultural Rojas, y así, según Tellas: "mirar la ciudad de otro modo, relacionar el teatro con una escenografía histórica y reflexionar sobre las decisiones políticas que promueven ciertas formas de exhibición" (Werth, 2013: 790).

Por su parte, Territorios en conflicto, y en particular, la performance El ferrocarril es futuro de Patricio Larrambebere y Ezequiel Semo, realizada durante ese primer año del ciclo en 2017, establecía otro tipo de cruce con lo urbano al retomar como objeto de conflicto y problematización escénica el patrimonio ferroviario de nuestra ciudad, poniendo en tensión las políticas de conservación y restauración desarrolladas en estaciones puntuales de nuestra ciudad (González, 2018).

Estos ejemplos se vincularían con el concepto de ciudad análoga, elaborado por Aldo Rossi, en su relectura de La arquitectura de la ciudad (1969), como aquella ciudad que emerge desde la obra de arte, es decir, un arte de la ciudad que recupera algún rasgo urbano y lo matiza dentro de la obra, y esto:

Nos obliga a tomar distancia, a poner en cuestión la naturalización de lo dado, a desconocernos para componer nuevas figuras que enriquezcan la cotidianidad rutinizada; nos enseña a mirar. ¿Qué pasaría si rompiendo el continuum de "nuestra" ciudad naturalizada comenzáramos a prestar atención a fragmentos inconexos quizá, que no forman sistema todavía, pero que están ahí y pueden tener condensados rasgos sustanciales para la comprensión de Buenos Aires? (...) ¿Qué otras ciudades análogas podrían armarse, diferentes del relato clásico de Buenos Aire que tenemos internalizado?" (Gorelik, 2004:150). 


\section{A modo de conclusión}

A lo largo de este trabajo hemos establecido diez modos de articular lo urbano y lo teatral-performático, en los que pudimos advertir diferentes grados de relación entre el arte, la ciudad, la memoria, lo pasado-presente, lo material y lo intangible. Abordamos cada caso con ejemplos concretos para explicar los aspectos comunes y los diferenciales al problematizar e intervenir lo urbano como escenario.

Así, entendemos que la memoria de una ciudad y su patrimonio cultural teatral pueden esparcirse y hasta alojarse de manera latente en prácticas, en imágenes, en gestos, en rincones de lo urbano que aguardan (aún sin saberlo) su des-ocultamiento a partir de lo teatral. Como dijimos al comienzo, será una mirada sensible la que permita visualizar esta dimensión estética de lo que nos rodea. Mirada dialéctica que no sólo se actualiza al recordar la Historia que ya es parte de nuestros circuitos urbanos diarios, sino que también se establece en el presente problematizando e irrumpiendo lo urbano cotidiano, reformulándolo, transformándolo, haciéndole emerger relatos latentes, coyunturas socio-políticas, acervos y archivos documentales que, por suceder en el espacio público, nos reconstituyen como ciudadanxs.

Asimismo, cada articulación del decálogo manifiesta un tipo diferente de relación con el presente y el pasado de la ciudad, con lo visible y lo que ya no lo es, con lo esperado dentro del espacio público y lo permitido y lo que se resiste en el margen, oscilando entre lo material y lo intangible de manera dual. Pensar y enumerar estos modos en formato de decálogo fue la inquietud perseguida. Sin duda, este procedimiento nos ordenará el análisis para trabajos futuros, en los que seguiremos repensando la configuración de una memoria urbana en constante transformación y las aristas posibles de su patrimonio cultural. 


\section{Dibliografía}

" Aguilar, M. Á. (2006). "La dimensión estética en la experiencia urbana". En: Lindón, A.; M. Á. Aguilar y D. Hiernaux (Coords.) Lugares e imaginarios en la metrópolis. Barcelona: Anthropos/ México: UAM. Pp.137-149.

» Ballent, A., M. Daguerre y G. Silvestre (1993). Cultura y proyecto urbano: la ciudad moderna. Buenos Aires: CEAL.

"Canclini, N. (1993). “Los usos sociales del patrimonio" en Florescano, E. (comp.) El Patrimonio Cultural de México. México: FCE. También disponible en: https:// www.iaph.es/export/sites/default/galerias/documentacion_migracion/Cuaderno/1233838647815_ph10.nestor_garcia_canclini.capii.pdf

»Chul Han, B. (2015). El aroma del tiempo. Un ensayo filosófico sobre el de demorarse. Barcelona: Herder.

»Debord, G. (1958). Définitions, Internationale Situacionniste 1, París. Citado en Giunta (2014).

»Diéguez Caballero, I. (2007). Escenarios liminales. Teatralidades, performances y política. Buenos Aires: Atuel.

"Feldman, M. (2016, octubre 18). "Matías Feldman estrena Proyecto Pruebas. Entrevista". Los inrockuptibles. Disponible en: https://losinrocks.com/ mat\%C3\%ADas-feldman-estrena-proyecto-pruebas-entrevista-a1321190oe85

» Féral, J. (2004). Teatro, teoría y práctica: más allá de las fronteras. Buenos Aires: Galerna.

» Giunta, A. (2014). ¿Cuándo empieza el arte contemporáneo?/ When Does Contemporary Art Begin? Buenos Aires: Fundación ArteBA.

" González, M. (2015). La Organización Negra. Performances urbanas entre la vanguardia y el espectáculo. Interzona: Buenos Aires.

»González, M.(2016). "La ciudad y sus circuitos teatrales: pensando los modos de producción de la actividad contemporánea”. Reflexión Académica en Diseño y Comunicación. Año XVII, Vol. 28. Universidad de Palermo.

»González, M. (2018). "La memoria entre baldosas y ferrocarriles. Dos performances en torno a la historia cultural de Buenos Aires", Investigación Teatral. Revista de Artes escénicas y performatividad, Vol. 10, No. 14, Centro de Estudios, Creación y Documentación de las Artes de la Universidad Veracruzana, México, Octubre 2018-marzo 2019. pp. 30-47.

»Gorelik, A. (1998). “Correspondencias. La ciudad análoga como puente entre ciudad y cultura”. Block, No.3, diciembre. Pp.88-97.

» Gorelik, A. (2004). Miradas sobre Buenos Aires. Historia cultural y crítica urbana. Buenos Aires: Siglo XXI.

"Norah, P. (1997). Les lieuxs de mémoire. París: Gallimard.

» Rossi, A. (1969). La arquitectura de la ciudad. Padua: Marsilio Editores. 2da edición. [Citado en Gorelik (1998)].

»Vedda, M. (2008). “Calles sin recuerdo: la fenomenología de la gran ciudad en Siegfried Kracauer y Walter Benjamin" en Buchenhorst, Ralph y Miguel Vedda (eds.) Observaciones Urbanas: Walter Benjamin y las nuevas ciudades. Buenos Ai- 
res: Editorial Gorla. Pp.83-94.

»Werth, B. (2013). "Ritos íntimos y propuestas éticas en el Proyecto Museos de Vivi Tellas", Rev. Bras. Estudos Presenca, Porto Alegre, Vol. 3, No. 3, set-dez,2013, pp. 789-804. Disponible en: http://www.scielo.br/pdf/rbep/v3n3/2237-266orbep-3-03-00789.pdf 